\title{
EFEKTIVITAS METODE BERNYANYI TERHADAP KEMAMPUAN FONASI MAHASISWA
}

\author{
Samsul Anam*1, Dewi Lestari ${ }^{2}$, Awalludin $^{3}$ \\ $1,2,3$ Program Studi Pendidikan Bahasa dan Sastra Indonesia, Universitas Baturaja \\ JIn. Ratu Penghulu No.2301, Karang Sari, Baturaja, Tj. Baru, Kec. Baturaja Timur, \\ Kabupaten Ogan Komering Ulu, Sumatera Selatan, Indonesia \\ Email: syamsulanam515@gmail.com¹, lestaridewiyusuf@gmail.com ${ }^{2}$, \\ awalludinawri@gmail.com ${ }^{3}$
}

\begin{abstract}
Abstrak
Tujuan penelitian ini adalah untuk mengetahui efektivitas metode bernyanyi terhadap kemampuan fonasi mahasiswa. Metode yang digunakan adalah metode eksperimen dengan model pre-eskperimental design one group pretest-posstest. Teknik pengumpulan data menggunakan teknik tes essay. Sampel dalam penelitian ini adalah kelas A.2.1 dengan jumlah 39 mahasiswa. Analisis data menggunakan rumus $t$ test dengan menggunakan program IBM SPSS 24. Dari hasil penelitian menunjukkan bahwa metode bernyanyi efektif meningkatkan kemampuan fonasi mahasiswa pada Mata Kuliah Fonologi. Efektivitas metode bernyanyi ini dibuktikan dengan hasil pretest dengan nilai rata-rata mahasiswa adalah 83.7 dengan kategori baik sekali, sedangkan hasil posttest 85,4 juga dengan kategori baik sekali. Berdasarkan hasil analisis uji statistik dengan menggunakan SPSS 24 dapat dijelaskan bahwa nilai rata-rata yang diperoleh adalah 1,65 dengan standar deviasi 14,391, dan nilai rata-rata standar error 2,433. Dari hasil analisis data tersebut diperoleh nilai $t$ tes sebesar 3,970 dengan df 34 .
\end{abstract}

Kata kunci: efektivitas, metode bernyanyi, kemampuan fonasi, mahasiswa

\section{THE EFFECTIVENESS OF THE SINGING METHOD ON STUDENTS' PHONATIO'N ABILITIES}

\begin{abstract}
The purpose of this study was to determine the effectiveness of the singing method on students' phonation abilities. The method used is an experimental method with a pre-experimental model design one group pretest-posstest. Data collection techniques using essay test techniques. The sample in this study was class A.2.1 with a total of 39 students. The data analysis used the $t$ test formula using the IBM SPSS 24 program. The results showed that the singing method was effective in improving students' phonation skills in the Phonology course. The effectiveness of this singing method was proven by the results of the pretest with the student's average score of 83.7 with a very good category, while the posttest results of 85.4 were also in a very good category. Based on the results of statistical test analysis using SPSS 24, it can be explained that the average value obtained is 1.65 with a standard deviation of 14.391 , and the average standard error value is 2.433 . From the results of the data analysis, the $t$ test value is 3,970 with a df of 34 .
\end{abstract}

Keywords: effectiveness, singing method, phonation ability, students 


\section{A. Pendahuluan}

Pemahaman tentang fonologi bagi calon sarjana pada Program Studi Pendidikan Bahasa dan Sastra Indonesia penting dilakukan karena lulusan dari program studi ini diharapkan benar-benar menjadi pribadi yang handal (fasohah) dalam berbahasa Indonesia dengan keseluruhan komponen kebahasaan yang ada. Seyogyanya, sarjana di bidang pengajaran bahasa yang baik bukan hanya pintar merangkai kalimat, memilih diksi, dan berimajinasi, tetapi juga harus mampu dan cermat mengucapkan fonem per fonem secara tepat dan fasih (Cholifah, 2019:132-133). Hal ini sesuai dengan tujuan pendidikan di era 5.0 mahasiswa bukan hanya harus mampu menguasai ilmu pengetahuan khususnya ilmu fonologi, tetapi melalui pembelajaran fonologi mahasiswa mampu menguasai keterampilan critical thinking and problem solving (daya berpikir kritis dan memecahkan masalah), creativity and innovation (kreativitas dan inovasi), communication skill (kemampuan berkomunikasi), collaboration (kerja sama), dan confidence (membangun kepercayaan diri) (Karto dkk., 2019:2718; Kusmiarti dkk., 2020).

Dalam kajian fonologi, bahasan tentang artikulasi tercantum dalam materi fonasi yang mengkaji tentang proses penghasilan bunyi dan pengelompokannya (Kasim, 2020:131-133; Muslich, 2012). Dalam materi ini, mahasiswa diajak untuki mengenal dan memahami bagaimana bunyi dihasilkan, organ apa saja yang terlibat, dan bagaimana pengelompokan bunyi-bunyi bahasa tersebut dengan mengacu pada organ yang menghasilkan. Dampak yang diharapkan dari pemberian materi ini adalah mahasiswa mampu mengamati bagaimanakah praktik pelafalan yang selama ini dilakukan, kesalahan pelafalan bunyi-bunyi apa saja yang sering terjadi, mampu melakukan perbaikan dari kesalahan-kesalahan yang ada, serta dapat dengan mudah mengidentifikasi klasifikasi bunyi yang ada dengan mengacu pada organ yang menghasilkan. Selain membantu memperbaiki kesalahan artikulasi yang terjadi pada diri mahasiswa sendiri, pemahaman tentang fonasi juga membantu mahasiswa untuk memberikan penjelasan kepada 
pembelajar bahasa bagaimana cara artikulasi yang benar dengan mengenalkan organ dan cara pengucapan yang benar dari bunyi-bunyi yang bersangkutan.

Hal yang masih menjadi hambatan adalah pemahaman tentang artikulasiartikulasi bunyi bahasa sangat bergantung dengan pemahaman mahasiswa terhadap nama-nama organ artikulasi dan cara artikulasi bunyi yang kesemuanya harus dipahami dalam bahasa latin. Contoh bunyi /F/ yang disebut sebagai bunyi labiodental frikatif. Hal ini dikarenakan bunyi tersebut dihasilkan dari perpaduan antara bibir 'labial' dan gigi 'dental' dengan cara penghambatan udara oleh kedua organ tersebut secara tidak total (Nafisah, 2017:70-72).

Berdasarkan observasi pembelajaran yang selama ini dilakukan, mahasiswa masih sangat lemah dalam menghafal nama-nama organ ucap yang meski dipahami dalam proses fonasi, sehingga pemahaman terhadap artikulasi dan identifikasi klasifikasi bunyi yang ada masih sangat lemah. Keberadaan namanama organ ucap yang keseluruhan menggunakan bahasa latin sepertinya masih menjadi momok bagi mahasiswa. Oleh karena itu, peneliti merasa perlu untuk mencoba menggunakan metode baru yang sekira dapat memecahkan permasalahan tersebut, salah satu metode yang ingin diterapkan peneliti adalah metode bernyanyi.

Metode bernyanyi merupakan metode pengajaran yang dilakukan dengan cara berdendang, dengan nada yang enak didengar, dan dengan kata-kata yang mudah diingat (Permatsari dkk., 2019:231; Depdikbud, 1994:1). Dengan bernyanyi peserta didik akan merasa senang dan berada dalam situasi yang nyaman. Bernyanyi juga dapat mewakili ekspresi seseorang dalam mengungkapkan emosinya (Hermawati \& Suyadi, 2020:66-67). Hal ini seiring dengan pendapat Rahman (2002:92) yang mengungkapkan bahwa kemampuan apresiasi akan berkembang melalui bernyanyi dan musik karena bernyanyi merupakan alat untuk mengungkapkan pikiran dan perasaan dalam bentuk emosi. Dalam prakteknya, mahasiswa akan diajak untuk berdendang mengikuti nada lagu tertentu dengan lirik materi hafalan seputar organ ucap dan jenis-jenis bunyi.

Hasil penelitian Widiani dkk. (2019) menunjukkan bahwa terdapat pengaruh metode bernyanyi melalui media audio visual dalam meningkatkan keterampilan 
berbicara anak kelompok A TK Triamarta Kediri Tabanan Tahun Ajaran 2018/2019. Kemudian, Joni (2019) juga melakukan penelitian dengan menerapkan metode bernyanyi dalam meningkatkan kemampuan kosakata siswa dan hasilnya terjadi peningkatan yang signifikan kemampuan kosakata siswa setelah diterapkannya kemampuan bernyanyi anak.

Berdasarkan penelitian terdahulu menunjukkan bahwa metode bernyanyi belum pernah diterapkan dalam meningkatkan efektivitas kemampuan fonasi mahasiswa. Untuk itu, dalam penelitian ini akan menguji hipotesis metode bernyanyi efektif meningkatkan kemampuan fonasi mahasiswa ada Mata Kuliah Fonologi pada kelas kelas A.2.1. dan A.2.2. Program Studi Pendidikan Bahasa dan Sastra Indonesia, FKIP Universitas Baturaja angkatan 2018/2019.

\section{B. Metode Penelitian}

Metode penelitian yang digunakan yaitu metode eksperimen. Metode eksperimen ini akan mencoba menjawab hipotesis penelitian yaitu metode bernyanyi efektif meningkatkan kemampuan fonasi mahasiswa pada Mata Kuliah Fonologi. Desain eksperimen menggunakan Pre-Eskperimental Design. Bentuk Pre-Eskperimental Design yang digunakan adalah One Group Pretest-Posstest, yakni memberi tes sebelum dan sesudah diberi perlakuan pada kelas yang sama (Arikunto, 2014; Sugiyono, 2011). Dengan demikian, hasil perlakuan lebih akurat karena dapat membandingkan keadaan sebelum dan setelah diberi perlakuan.

Populasi dalam penelitian ini adalah seluruh mahasiswa yang menempuh Mata Kuliah Fonologi, terutama semester II angkatan 2018/2019 yang terdiri dari 2 kelas dengan jumlah 55 mahasiswa. Teknik pengambilan sampel menggunakan Simple Random Sampling dengan sampel penelitian kelas A.2.1 yang berjumlah 39 mahasiswa.

Teknik pengumpulan data yang digunakan dalam penelitian ini adalah teknik tes. Menurut Nurgiyantoro (2011:105), tes adalah salah satu bentuk pengukuran dan tes hanyalah merupakan salah satu satu cara untuk mendapat informasi (kompetensi, pengetahuan, keterampilan) tentang peserta didik. Untuk 
memperoleh data yang diperlukan dalam penelitian ini penulis menggunakan tes essay. Langkah yang dilakukan untuk mengumpulkan data yaitu menyusun instrumen penelitian dan melaksanakan tes pada mahasiswa kelas A.2.1.

Teknik penganalisian data merupakan teknik yang digunakan untuk mengelola data yang telah dikumpulkan dan telah diklarifikasikan menurut jenis dan fungsinya sesuai dengan tujuan penelitian. Teknik penganalisisan yang digunakan dalam penelitian ini adalah teknik deskriptif kuantitatif dengan bantuan SPSS 24. Adapun langkah yang dilakukan dalam penganalisisan data adalah sebagai berikut.

1. Memberikan penilaian terhadap hasil tes essay yang dilakukan dengan berpedoman pada acuan jawaban yang digunakan.

2. Menghitung skor individu.

3. Setelah semua hasil tes diperoleh, untuk mengetahui efektif atau tidaknya metode bernyanyi, penulis menggunakan rumus $\mathrm{t}$ "test" dengan menggunakan program IBM SPSS Statistik 24 Computer License.

4. Mendeskripsikan /menjelaskan hasil analisis data.

5. Membuat kesimpulan.

\section{Hasil Penelitian dan Pembahasan}

\section{Hasil Penelitian}

a. Nilai Tes Sebelum Menggunakan Metode Bernyanyi (Pretest)

Pretest dilakukan pada Kamis 21 Mei 2019. Tes awal ini dilakukan guna melihat kemampuan/pemahaman awal mahasiswa terhadap materi fonasi sebelum diterapkan metode bernyanyi. Pretest dilakukan pada mahasiswa sampel yaitu kelas A 21 Prodi Pendidikan Bahasa dan Sastra Indonesia yang berjumlah 39 orang. Hanya saja ketika test dilakukan, 4 mahasiswa tidak dapat hadir karena alasan berhenti dari perkuliahan. Pertanyaan yang diberikan kepada mahasiswa sampel berbentuk essay dengan jumlah 8 pertanyaan. Hasil nilai mahasiswa pada sesi ini dapat dilihat pada tabel berikut. 
Tabel 1. Deskripsi Nilai Tes Mahasiswa Sebelum Menggunakan Metode Bernyanyi

\begin{tabular}{|c|c|c|c|}
\hline No. & Nama Mahasiswa & Nilai & Keterangan \\
\hline 1 & LP & 82 & Baik Sekali \\
\hline 2 & MA & 95 & Baik Sekali \\
\hline 3 & RS & 54 & Kurang \\
\hline 4 & IAS & 88 & Baik Sekali \\
\hline 5 & EV & 50 & Kurang \\
\hline 6 & $\mathrm{~S}$ & 54 & Kurang \\
\hline 7 & OEA & 94 & Baik Sekali \\
\hline 8 & DF & 84 & Baik Sekali \\
\hline 9 & ZL & 67 & Baik \\
\hline 10 & RAA & 91 & Baik Sekali \\
\hline 11 & PS & 75 & Baik \\
\hline 12 & EYS & 92 & Baik Sekali \\
\hline 13 & LY & 89 & Baik Sekali \\
\hline 14 & $\mathrm{RM}$ & 84 & Baik Sekali \\
\hline 15 & EYS & 88 & Baik Sekali \\
\hline 16 & EF & 88 & Baik Sekali \\
\hline 17 & SF & 74 & Baik \\
\hline 18 & $\mathrm{OH}$ & 89 & Baik Sekali \\
\hline 19 & RLP & 87 & Baik Sekali \\
\hline 20 & LBU & 92 & Baik Sekali \\
\hline 21 & AS & 95 & Baik Sekali \\
\hline 22 & AMA & 86 & Baik Sekali \\
\hline 23 & AS & 83 & Baik Sekali \\
\hline 24 & TWA & 88 & Baik Sekali \\
\hline 25 & DS & 84 & Baik Sekali \\
\hline 26 & $\mathrm{DL}$ & 90 & Baik Sekali \\
\hline 27 & LS & 84 & Baik Sekali \\
\hline 28 & DW & 78 & Baik \\
\hline 29 & FS & 91 & Baik Sekali \\
\hline 30 & SW & 88 & Baik Sekali \\
\hline 31 & LM & 93 & Baik Sekali \\
\hline 32 & AYK & 95 & Baik Sekali \\
\hline 33 & AA & 96 & Baik Sekali \\
\hline 34 & IA & 92 & Baik Sekali \\
\hline \multirow[t]{2}{*}{35} & MS & 72 & Baik \\
\hline & Jumlah & 2932 & \\
\hline
\end{tabular}

Berdasarkan data di atas dapat dijelaskan bahwa kemampuan mahasiswa pada sesi ini sudah sangat baik dengan nilai rata-rata 83.7. Nilai tertinggi yang didapat adalah 96 dan nilai terendah adalah 50.

\section{b. Nilai Tes Setelah Menggunakan Metode Bernyanyi (Posttest)}

Posttest pada penelitian ini dilakukan pada Kamis, 18 Juli 2019. Tujuan diberikannya posttest adalah untuk melihat efek atau dampak dari metode yang

Silampari Bisa: Jurnal Penelitian Pendidikan Bahasa Indonesia, Daerah, dan Asing Vol. 3, No. 2, 2020 
telah diterapkan terhadap kemampuan mahasiswa sampel memahami materi penelitian (fonasi).

Sebelum posttest dilakukan, terlebih dahulu peneliti melakukan treatment terhadap mahasiswa sampel terkait metode yang digunakan. Perlakukan dilakukan sebanyak 2 kali, yaitu pada Kamis, 6 Juni 2019, dan Kamis, 20 Juni 2019. perlakuan dilakukan dengan menggunakan 4 buah lagu yang diharapkan dapat mempermudah mahasiswa memahami materi fonasi yang diberikan, terutama terkait organ artikulasi, klasifikasi bunyi, dan cara artikulasi. Keempat buah lagu tersebut adalah lagu Topi Saya Bundar, Sayang, Seribu Alasan, NaikNaik ke Puncak Gunung, dan Aishiteru II dengan muatan lirik yang telah disesuaikan dengan materi penelitian.

Tiga lagu pertama bersisi materi tentang organ artikulasi, lagu keempat berisi tentang cara artikulasi, dan lagu terakhir berisi materi tentang pengelompokan bunyi.

Nada lagu Topi Saya Bundar diambil secara utuh dan diulang beberapa kali, nada lagu Sayang hanya diambil pada bagian awal dan diulang beberapa kali, nada lagu Seribu Alasan hanya diambil pada bagian refferen, nada lagu NaikNaik ke Puncak Gunung juga diambil secara utuh dan diulang beberapa kali, sedangkan nada lagu Aishiteru // hanya diambil pada bagian refferen. Lirik-lirik lagu tersebut adalah sebagai berikut.

\section{Topi Saya Bundar (Organ Artikulasi) \\ Alat ucap kita semua ada tiga \\ Subglotal dan glotal juga supraglotal \\ Organ supra glotal itu ada dua \\ Rongga mulut atas juga rongga bawah \\ Rongga mulut atas bibirnya labial \\ Kalau gigi dental, gusi alveolar \\ Gusi alveolar, langit keras palatal \\ Langit lunak velar, anak tekak uvular \\ Rongga mulut bawah bibirnya labial \\ Dental dan apikal, laminal dan dorsal}




\section{Sayang (Organ Artikulasi)}

Alat ucap manusia semua ada tiga

Subglotal, glotal dan supra

Organ supraglotal ada dua

Rongga atas rongga bawah

Bibir atasnya labial, kalau gigi dental

Gusi atas alveolar

Langit keras itulah palatal

Velar dan juga uvular

Bibir bawahnya labial, gigi masih dental

Ujung lidahnya apikal

Tengah lidah itulah laminal

Dorsal dan juga radikal

\section{Seribu Alasan (Organ Artikulasi)}

Bibir labial, kalau gigi dental

Alveolar, ada juga palatal

Langit lunak itu velar, anak tekak uvular

Bibir labial, gigi masih dental

Ujung apikal, kalau tengah laminal,

pangkal lidah itu dorsal, akar lidah radikal

\section{Naik-Naik ke Puncak Gunung (Cara Artikulasi)}

Cara artikulasi kita semua ada lima

Hambat plosif, frikatif dan trill

Afrikatif lateral

Hambat tahan secara total

Lalu lepas secara cepat

Frikatif ditahan tak total

Masih bisa keluar

Afrikatif seperti plosif ditahan dengan total Lalu lepas secara pelan tanpa ada letupan

Trill ditahan lalu lepaskan

dengan cara berulang

Dan lateral dihambat total

Nylonong lewat sampingan

\section{Aishiteru II (Pengelompokan Bunyi)}

Bilabial /P/,/B/,/F/ dan /T/ apiko dental

Kalau /D/ itu apiko alveolar

/C/ lamino palatal, /G/,/K/,/Q/ dorso velar

Silampari Bisa: Jurnal Penelitian Pendidikan Bahasa Indonesia, Daerah, dan Asing Vol. 3, No. 2, 2020 
Setelah perlakuan diberikan, mahasiswa diberikan posttest yang dilakukan pada 18 Juli 2019. Materi posttest berisi pemahaman tentang organ artikulasi, cara artikulasi dan pengelompokan bunyi dan diberikan dengan tujuan untuk mengukur kemampuan mahasiswa setelah perlakuan diberikan. Pertanyaan diberikan dalam bentuk essay dengan jumlah pertanyaan sebanyak 5 pertanyaan.

Tabel 2. Deskripsi Nilai Tes Mahasiswa Setelah Menggunakan Metode Bernyanyi

\begin{tabular}{|c|c|c|c|}
\hline No. & Nama Mahasiswa & Nilai & Keteranqan \\
\hline 1 & LP & 83 & Baik Sekali \\
\hline 2 & MA & 94 & Baik Sekali \\
\hline 3 & RS & 88 & Baik Sekali \\
\hline 4 & IAS & 90 & Baik Sekali \\
\hline 5 & EV & 75 & Baik \\
\hline 6 & $\mathrm{~S}$ & 82 & Baik Sekali \\
\hline 7 & OEA & 95 & Baik Sekali \\
\hline 8 & $\mathrm{DF}$ & 85 & Baik Sekali \\
\hline 9 & ZL & 70 & Baik \\
\hline 10 & RAA & 92 & Baik Sekali \\
\hline 11 & PS & 76 & Baik \\
\hline 12 & EYS & 90 & Baik Sekali \\
\hline 13 & LY & 85 & Baik Sekali \\
\hline 14 & RM & 85 & Baik Sekali \\
\hline 15 & EYS & 86 & Baik Sekali \\
\hline 16 & EF & 90 & Baik Sekali \\
\hline 17 & SF & 75 & Baik \\
\hline 18 & $\mathrm{OH}$ & 69 & Baik \\
\hline 19 & RLP & 85 & Baik Sekali \\
\hline 20 & LBU & 93 & Baik Sekali \\
\hline 21 & AS & 90 & Baik Sekali \\
\hline 22 & AMA & 83 & Baik Sekali \\
\hline 23 & AS & 90 & Baik Sekali \\
\hline 24 & TWA & 86 & Baik Sekali \\
\hline 25 & DS & 85 & Baik Sekali \\
\hline 26 & $\mathrm{DL}$ & 89 & Baik Sekali \\
\hline 27 & LS & 85 & Baik Sekali \\
\hline 28 & DW & 81 & Baik Sekali \\
\hline 29 & FS & 88 & Baik Sekali \\
\hline 30 & SW & 81 & Baik Sekali \\
\hline 31 & LM & 90 & Baik Sekali \\
\hline 32 & AYK & 92 & Baik Sekali \\
\hline 33 & AA & 97 & Baik Sekali \\
\hline 34 & IA & 90 & Baik Sekali \\
\hline \multirow[t]{2}{*}{35} & MS & 75 & Baik \\
\hline & Jumlah & 2990 & \\
\hline
\end{tabular}

Hasil posttest menunjukkan bahwa nilai tertinggi mahasiswa adalah 97 dengan nilai terendah 69. Nilai rata-rata yang didapat adalah 85.4 dengan kategori baik sekali.

Silampari Bisa: Jurnal Penelitian Pendidikan Bahasa Indonesia, Daerah, dan Asing Vol. 3, No. 2, 2020 
c. Hasil Uji t test menggunakan Program IBM SPSS Statistik 24

Uji statistik ini dilakukan untuk memperoleh informasi tentang ada atau tidak perbedaan kemampuan mahasiswa pada materi fonasi sebelum dan setelah digunakan metode bernyanyi. Uji statistik yang dilakukan adalah uji statistik parametris. Statistik parametris digunakan untuk menguji hipotesis komparatif rata-rata dengan menggunakan uji paired test dengan SPSS 24 berikut ini.

Tabel 3. Hasil Uji Paired Test dalam Bentuk Paired Samples Statistik

\begin{tabular}{|c|c|c|c|c|c|}
\hline \multicolumn{6}{|c|}{ Paired Samples Statistics } \\
\hline & & Mean & $\mathrm{N}$ & Std. Deviation & $\begin{array}{l}\text { Std. Error } \\
\text { Mean }\end{array}$ \\
\hline \multirow[t]{2}{*}{ Pair 1} & Pretes & 83,77 & 35 & 11,840 & 2,001 \\
\hline & Postes & 85,42 & 35 & 12,702 & 2,147 \\
\hline
\end{tabular}

Tabel 4. Hasil Uji Paired Test dalam Bentuk Paired Samples Correlation

\begin{tabular}{lrrr|r}
\multicolumn{6}{c}{ Paired Samples Correlations } \\
& $\mathrm{N}$ & Correlation & \multicolumn{1}{c}{ Sig. } \\
\hline Pair 1 & Pretes \& Postes & 35 &, 314 &, 066 \\
\hline
\end{tabular}

Tabel 5. Hasil Uji Paired Test dalam Bentuk Paired Samples Test

\begin{tabular}{|c|c|c|c|c|c|c|c|c|c|}
\hline & & & $\mathrm{Pai}$ & $\begin{array}{l}\text { ed Sam } \\
\text { d Differe }\end{array}$ & $\begin{array}{l}\text { es Test } \\
\text { ees }\end{array}$ & & & & \\
\hline & & & Std. & $\begin{array}{l}\text { Std. } \\
\text { Error }\end{array}$ & $\begin{array}{r}95 \% \text { Co } \\
\text { Interva } \\
\text { Diffe }\end{array}$ & $\begin{array}{l}\text { fidence } \\
\text { of the } \\
\text { ance }\end{array}$ & & & Sig. \\
\hline & & Mean & Deviation & Mean & Lower & Upper & $t$ & $\mathrm{df}$ & tailed) \\
\hline $\begin{array}{l}\text { Pair } \\
1\end{array}$ & $\begin{array}{l}\text { Pretes - } \\
\text { Postes }\end{array}$ & 9,657 & 14,391 & 2,433 & 4,714 & 14,601 & 3,970 & 34 &, 000 \\
\hline
\end{tabular}

Berdasarkan hasil analisis uji statistik dari data pretest dan posttest yang sudah dilakukan dengan menggunakan SPSS 24 di atas dapat dijelaskan bahwa nilai rata-rata yang diperoleh adalah 9,657, dengan standar deviasi 14,391, dan nilai rata-rata standar eror 2,433. Dari data tersebut diperoleh nilai $t$ tes sebesar 3,970 dengan df 34 .

Hasil akhir penelitian menunjukkan bahwa metode bernyanyi efektif diterapkan pada pembelajaran fonologi khususnya pada materi fonasi. Hal ini ditandai dengan perbedaan hasil tes antara sebelum dan sesudah perlakuan, di 
mana nilai rata-rata posttest lebih tinggi daripada prestest dengan perbedaan margin angka atau mean sebesar 1,65.

\section{Pembahasan}

Hasil penelitian menunjukkan bahwa metode bernyanyi efektif meningkatkan kemampuan fonasi mahasiswa pada Mata Kuliah Fonologi. Hal ini tentunya sesuai dengan ekspektasi hipotesis yang peneliti ajukan sebelum penelitian dilakukan. Keberhasilan metode bernyanyi dalam meningkatkan kemampuan fonasi mahasiswa juga sama dengan penelitian sebelumnya yang dilakukan oleh Widiani dkk. (2019) dan Joni (2019). Hanya saja, penelitian Widiani dkk. (2019) dan Joni (2019) efektif meningkatkan keterampilan bahasa yang lain yaitu keterampilan berbicara dan kemampuan menguasai kosakata.

Dari hasil tes awal atau pretest dapat dijelaskan bahwa nilai rata-rata mahasiswa adalah 83.7 dengan kategori sangat baik. Secara umum mahasiswa mampu menjawab 8 pertanyaan essay yang diberikan dengan cukup baik, yang mana pada sesi ini nilai tertinggi adalah 96 dan nilai terendah 50. Pertanyaan yang diberikan pada tes awal ini mencakup pemahaman tentang organ artikulasi dan pengelompokan bunyi. Salah satu hal yang membuat nilai mahasiswa pada tes awal sudah sangat baik adalah sudah adanya bekal hafalan mahasiswa terhadap organ-organ ucap yang telah ditugaskan sebelumnya serta adanya latihan mengidentifikasi bunyi yang dilakukan sebelum-sebelumnya dengan bekal hafalan yang ada. Hanya saja, hafalan pada saat itu belum menggunakan perantara lagu, sebagaimana yang akan diterapkan pada posttest.

Setelah pretest dilakukan, peneliti memberikan treatment kepada mahasiswa. Perlakuan dilakukann sebanyak 2 kali dengan 3 pilihan lagu terkait pemahaman materi tentang organ artikulasi, 1 lagu tentang organ artikulasi, dan 1 lagu tentang klasifikasi bunyi. Pemahaman tentang organ artikulasi mendapat porsi lebih besar karena pemahaman tentang materi ini menjadi titik tolak pemahaman materi-materi berikutnya. Ketika treatment diberikan, mahasiswa sangat antusias untuk mengikuti lagu-lagu yang ada dan merasa lebih rileks dan terhibur. Setelah kelas berakhir pun, mahasiswa masih semangat untuk 
melantunkan lagu-lagu yang baru dipelajari di luar kelas. Tentunya hal ini akan berdampak pada posttest yang akan dilakukan.

Hasil posttest menunjukkan, kemampuan mahasiswa memahami materi fonasi semakin lebih baik dari sebelumnya, meski masih pada kategori yang sama yaitu baik sekali dengan nilai rata-rata 85,4. Nilai tertinggi 97 dan nilai terendah 69. Jika dibandingkan dengan hasil pretest, tentunya terdapat kenaikan yang signifikan antara hasil tes awal dan tes setelah perlakuan. Hal ini menunjukkan bahwa perlakuan yang telah diberikan memberikan hasil yang cukup menggembirakan.

Jika dicermati, secara umum nilai mahasiswa memang tidak mengalami peningkatan yang begitu jauh. Hal ini dikarenakan level nilai mahasiswa pada tes awal juga sudah baik sekali, yang mana kebanyakan nilai mahasiswa sudah berada pada level baik dan baik sekali dengan rentang 70-90. Hanya saja, pada tes akhir jumlah mahasiswa yang mendapatkan nilai dengan kategori kurang dan cukup sudah sangat berkurang. Jika dilihat dari data nilai mahasiswa pada tabel 4, maka dapat dijelaskan bahwa pada tes awal masih ditemukan 3 mahasiswa dengan kategori nilai kurang dengan rentang antara 50-54. Sedangkan pada tes akhir, nilai mahasiswa dengan kategori kurang sudah tidak ditemukan lagi. Di sisi lain, jumlah mahasiswa yang mendapatkan kategori baik sekali pun juga naik secara signifikan. Pada tes awal, jumlah mahasiswa dengan kategori ini hanya berjumlah 27, sedangkan pada tes akhir berjumlah 29.

Secara umum peneliti masih kurang puas dengan hasil penerapan metode bernyanyi pada penelitian ini. Hal ini dikarenakan perbedaan nilai rata-rata mahasiswa yang tidak begitu jauh. Hasil ini mungkin disebabkan karena kondisi tes awal dan setelah perlakuan yang berbeda. Ketika tes awal diberikan, pemahaman mahasiswa terhadap materi fonasi masih segar. Hal ini disebabkan karena waktu tes awal dengan diberikannya materi fonasi tidaklah begitu lama, sehingga mahasiswa masih dapat mereview ingatan mereka dengan baik. Sementara itu, ketika posttest diberikan mahasiswa sudah disibukkan dengan materi-materi lain yang harus diterima. Namun meskipun demikian, ada dampak 
positif dari penerapan metode bernyanti tersebut. Pertama, nilai tertinggi mahasiswa pada posttest lebih tinggi dibanding pretest, yaitu 97 dan 96 . Selain itu, pemahaman mahasiswa tentang cara artikulasi juga lebih baik dibanding sebelumnya.

Dari uraian pembahasan di atas dapat disimpulkan bahwa penggunaan metode bernyanyi efektif meningkatkan kemampuan fonasi mahasiswa. Oleh karena itu, metode ini dapat diujicobakan pada pembelajaran Mata Kuliah Fonologi berikutnya dengan rancangan waktu yang lebih tepat lagi. Penerapan metode pada waktu yang lebih pas lagi tentunya akan membuat metode ini dapat memberikan dampak yang lebih signifikan lagi. Keberhasilan penggunaan metode bernyanyi ini juga karena peran dosen dalam mengelola kelas dengan baik, karena sebaik apapun metode pembelajaran yang digunakan apabila pengajar tidak bisa mengelola kelas dengan baik maka tujuan pembelajaran tidak bisa tercapai secara maksimal (Noermanzah, 2015:275).

\section{Simpulan}

Hasil penelitian menunjukkan bahwa metode bernyanyi efektif meningkatkan kemampuan fonasi mahasiswa pada Mata Kuliah Fonologi. Hal ini dibuktikan dari hasil tes awal atau pretest, nilai rata-rata mahasiswa adalah 83.7 dengan kategori baik sekali. Kemudian, hasil posttest menunjukkan bahwa pemahaman mahasiswa tentang materi fonasi juga berada pada kategori baik sekali dengan nilai rata-rata 85,4. Nilai tertinggi 97 dan nilai terendah 69.

Berdasarkan hasil analisis uji statistik dari data pretest dan posttest yang sudah dilakukan dengan menggunakan SPSS 24 dapat dijelaskan bahwa nilai rata-rata yang diperoleh adalah 1,65 dengan standar deviasi 14,391 , dan nilai rata-rata standar eror 2,433. Dari data tersebut diperoleh nilai $t$ tes sebesar 3,970 dengan df 34. Hasil akhir penelitian menunjukkan bahwa metode bernyanyi efektif diterapkan pada pembelajaran fonologi khususnya pada materi fonasi. Hal ini ditandai dengan perbedaan hasil tes antara sebelum dan sesudah perlakuan, yang mana nilai rata-rata posttest lebih tinggi daripada prestest dengan perbedaan margin angka atau mean sebesar 1,65. 


\section{Daftar Pustaka}

Arikunto, S. (2014). Prosedur Penelitian: Suatu Pendekatan Praktik. Jakarta: Rineka Cipta.

Cholifah, M. (2019). Pengajaran Bahasa Berbasis Tugas (Task Based Language Teaching): Pendekatan yang Efektif dalam Pengajaran Bahasa Inggris. Jurnal IImiah Bahasa dan Sastra, 4(2), 132-133. doi:10.21067/jibs.v4i2.3187

Depdikbud. (1994). Petunjuk Teknis Proses Belajar Mengajar di Taman KanakKanak. Jakarta: Proyek Peningkatan Mutu Taman Kanak-Kanak.

Hermawati, H., \& Suyadi, S. (2020). Pembelajaran Somamun melalui Metode Bernyanyi pada Anak Usia Dini di TK Simahate Takengon. Early Childhood: Jurnal Pendidikan, 4(1), 66-67. doi:10.35568/earlychildhood.v4i1.791

Joni, J. (2019). Penerapan Metode Bernyanyi untuk Meningkatkan Perkembangan Kosa Kata Anak Usia Dini. Journal on Early Childhood Education Research (JOECHER), 1(1), 1-15. doi:10.37985/joecher.v1i1.2

Karto, Suhartono, Susetyo, Noermanzah, Maisarah, I. (2019). The Differences Ability in Writing Descriptive Texts by Using Chain Writing and Conventional Methods. International Journal of Scientific \& Technology Research, 8(10), 2718.

Kasim, M. R. (2020). Kepentingan Variasi Fonologi Kata Pinjaman Bahasa Melayu yang Dituturkan oleh Orang Asli Jakun kepada Kajian Linguistik Melayu: Analisis Fonologi Atur Rumus. Jurnal Bahasa, 20(1), 131-132. http://jurnal.dbp.my/index.php/jurnalbahasa/article/view/7899

Kusmiarti, R., Yuniati, I., \& Noermanzah. (2020). Improving Student Communication Skills In Learning Indonesian Language Through Collaborative Learning. Retrieved from osf.io/9km3u. International Journal of Scientific and Technology Research, 9(1).

Muslich, M. (2012). Fonologi Bahasa Indonesia. Jakarta: PT Bumi Aksara.

Nafisah, S. (2017). Proses Fonologis dan Pengkaidahannya dalam Kajian Fonologi Generatif. Deiksis, 9(01), 70-72. doi:10.30998/deiksis.v9i01.940

Noermanzah, N. (2015). Peran Dosen Bahasa dan Sastra Indonesia dalam Mempertahankan Bahasa Indonesia sebagai Alat Pemersatu Negara Kesatuan Republik Indonesia pada Era Globalisasi. In Prosiding Seminar Nasional Bulan Bahasa 2015. Unit Penerbitan FKIP Universitas Bengkulu, p. 275. http://repository.unib.ac.id/11133/ 
Nurgiyantoro, B. (2011). Penilaian Pembelajaran Bahasa. Yogyakarta: BPFEYogyakarta.

Permatsari, D., Rohaeti, E. E., \& Westhisi, S. M. (2019). Meningkatkan Kemampuan Berpikir Logis Anak Usia Dini melalui Metode Bernyanyi pada Anak Kelompok B. CERIA (Cerdas Energik Responsif Inovatif Adaptif), 2(5), 230. doi:10.22460/ceria.v2i5.p230-236

Rahman, H. S. (2002). Konsep Dasar Pendidikan Anak Usia Dini. Yogyakarta: PGTKI Press.

Sugiyono. (2011). Metode Penelitian Kuantitatif Kualitatif dan R\&D. Bandung: Alfabeta.

Widiani, N. L. W. D., Putra, I K. A., \& Agustika, G. N. S. (2019). Pengaruh Metode Bernyanyi melalui Media Audio Visual terhadap Keterampilan Berbicara Anak Kelompok A TK Triamarta Kediri Tabanan Tahun Ajaran 2018/2019. Jurnal Pendidikan Anak Usia Dini Undiksha, 7(1), 68. doi:10.23887/paud.v7i1.18760 